\title{
PENGARUH VAKSINASI MATERNAL ANTI-AEROMONAS HYDROPHILA TERHADAP BENIH IKAN LELE DUMBO (Clarias sp.) YANG DIHASILKANNYA
}

\author{
Taukhid $^{*}$ dan Dayat Bastiawan ${ }^{*}$
}

\begin{abstract}
ABSTRAK
Penelitian vaksinasi maternal pada ikan lele telah dilakukan di panti benih Unit Pengembangan Budidaya Air Tawar (UPBAT) Cijengkol dan laboratorium penyakit ikan Balai Penelitian Perikanan Air Tawar. Induk lele sebelum dipijahkan diberi vaksin secara Intra Peritoneal (IP) pada saat Tingkat Kematangan Gonad I awal (4 minggu sebelum dipijahkan) dan TKG II awal (2 minggu sebelum dipijahkan) dengan dosis $0,2 \mathrm{ml} / \mathrm{kg}$, $0,4 \mathrm{ml} / \mathrm{kg}$ dan $0,8 \mathrm{ml} / \mathrm{kg}$ berat badan. Sedangkan kelompok lainnya disuntik dengan Phosphate Buffer Saline (PBS) sebagai kontrol.
\end{abstract}

Pengamatan adanya transfer antibodi dilakukan terhadap serum darah induk sebelum vaksinasi dan sesudah proses pemijahan, ekstrak telur dan ekstrak benih umur 7; 14; 21 dan 28 hari melalui uji aglutinasi langsung, sedangkan peran antibodi terhadap benih dilakukan melalui uji tantang dan peningkatan persentase kelangsungan hidup setelah pemeliharaan di kolam selama 2 bulan.

Titer antibodi tertinggi dicapai pada benih hasil pemijahan induk yang divaksin saat TKG II awal untuk semua dosis yang diterapkan. Rataan mortalitas benih hasil pemijahan induk vaksinasi maternal saat uji tantang I berkisar antara $2,22-33,33 \%$ pada saat umur 21 hari dan berkisar antara 30,00-68,33\% pada umur 35 hari; sedangkan benih hasil pemijahan induk tidak divaksin masing-masing sebesar $75,56 \%$ dan $93,33 \%$. Kelangsungan hidup kelompok benih hasil pemijahan induk yang divaksin setelah dipelihara selama 2 bulan di kolam berkisar antara $69,01-79,93 \%$, sedangkan kelompok ikan kontrol sebesar $37,64 \%$.

\section{ABSTRACT: Effect of Maternal Vaccination Anti-Aeromonas bydropbila on Dumbo catfish (Clarias sp.) Broodstocks to Their Fries. By Taukbid and Dayat Bastiaroan.}

A study on dumbo catfish maternal vaccination was done at the Freshwater Aquaculture Development Unit (FADU) Cijengkol and fish diseases laboratory of the Research Institute for Freshwater Fisheries. Dumbo catfish broodstocks were vaccinated intraperitoneally at Gonado Somatic Index (GSI) I and II at the doses of $0.2 \mathrm{ml} / \mathrm{kg}, 0.4$ $\mathrm{ml} / \mathrm{kg}$ and $0.8 \mathrm{ml} / \mathrm{kg}$ body weight. Unvaccinated broodstock were used as control.

Antibody titres on broodstock serum, eggs and fry soluble extract were examined by agglutination titre antibody test, and the immun protection to the fry were measured by challenge test and the survival rate after rearing them 2 month in the ponds.

Antibody titre of the fry hatched from vaccinated broodstock at GSI II is higher than vaccinated broodstock at GSI I for all the vaccine doses application. The mortality of fry obtained from vaccinated broodstocks after challenged were $2.2-33.3 \%$ at 21 old days and $30.0-68.3 \%$ at 35 old days respectively; meanwhile the mortality of control fry were $75.6 \%$ and $93.3 \%$ at 21 and 35 old days respectively. The survival rate after reared 2 months in the ponds were $69.0-79.9 \%$ of vaccinated broodstock's fry and $37.64 \%$ of control fry.

KEYWORDS: Vaccination, Aeromonas bydrophila, Clarias

*) Peneliti Balai Penelitian Perikanan Air Tawar, Sukamandi 


\section{PENDAHULUAN}

Telah lama diketahui bahwa pada hewan vertebrata tingkat tinggi transfer kekebalan maternal cukup berperan dalam meningkatkan daya resistensi anaknya terhadap agen penyakit sebelum sistem immunitasnya berkembang baik (Kawahara et al., 1993). Pada ikan, kekebalan induk betina terhadap suatu jenis penyakit yang diperoleh melalui vaksinasi aktif akan ditransfer kepada keturunannya meskipun dalam kadar yang relatif rendah dan bersifat temporer dengan peluruhan yang cukup cepat (Taukhid dan Bastiawan, 1993). Informasi adanya transfer kekebalan maternal pada ikan masih sangat terbatas dan baru dilaporkan pada beberapa spesies ikan (Bly et al., 1986; Takahashi dan Kawahara, 1987; Mor dan Avtalion, 1988 \& 1990; Kawahara et al., 1993; Taukhid dan Bastiawan, 1993 dan Sin et al., 1994). Fenomena tersebut merupakan teknik alternatif dalam upaya mengantisipasi tingginya angka kematian benih ikan pada umur kurang dari satu bulan, yaitu pada saat tubuh ikan belum mampu memproduksi kekebalan spesifik terhadap agen penyakit yang sering menimbulkan kematian di awal kehidupan ikan.

Bakteri Aeromonas bydrophila merupakan salah satu patogen yang sering menyerang ikan air tawar dan menginfeksi pada semua fase kehidupan ikan. Strain virulen dari jenis bakteri ini diduga merupakan patogen utama penyebab wabah penyakit di Indonesia pada dekade 1980-an yang menyerang beberapa jenis ikan air tawar dan mengakibatkan kerugian ratusan juta rupiah (Eidman et al., 1981; Djajadiredja dan Cholik, 1982 dan Kabata, 1985). Kasus-kasus serupa yang disebabkan oleh jenis bakteri tersebut dalam skala yang bervariasi masih sering terjadi hingga saat ini. Penggunaan antibiotika sudah banyak diterapkan untuk menanggulangi serangan bakteri $A$. bydropbila, hingga pada akhirnya dikembangkan teknik vaksinasi untuk pencegahan dini dari serangan bakteri tersebut.

Penelitian ini bertujuan untuk mengetahui saat pemberian dan dosis vaksinasi maternal anti-Aeromonas bydrophila pada induk betina lele dumbo (Clarias sp.) yang memberikan tingkat proteksi paling baik dari perlakuan yang diterapkan terhadap benih yang dihasilkannya.

\section{METODE}

\section{Waktu dan Tempat}

Penelitian dilakukan pada bulan Juli 1994 hingga Januari 1995 di perkolaman dan panti benih Unit Pengembangan Budidaya Air Tawar (UPBAT) Cijengkol, Subang. Pemeliharaan induk pra-vaksinasi dilakukan dalam kolam beton $3 \times 6 \mathrm{~m}^{2}$ yang dipisahkan antara kelompok induk jantan dan betina. Setelah diberi perlakuan, pemisahan masing-masing kelompok induk dilakukan dalam bak beton $1,5 \times 2,25 \mathrm{~m}^{2}$. Proses pemijahan serentak dilakukan di panti 
benih, demikian pula uji tantang terhadap benih-benih yang dihasilkan. Pengamatan titer antibodi dilakukan di laboratorium penyakit ikan, Balai Penelitian Perikanan Air Tawar.

\section{Ikan Uji}

Ikan yang digunakan adalah induk lele dumbo (Clarias sp.) sebanyak 40 pasang dengan bobot tubuh antara 530-1.820 g/ekor atau bobot rataan 895 g/ekor. Selama masa adaptasi, induk ikan diberi pakan buatan berupa pelet komersial (kadar protein 30\%) sebanyak 3-5\% bobot tubuh per hari yang diberikan pada pagi dan sore hari.

Benih hasil induk uji diberi pakan campuran Artemia salina dan Dapbnia secara ad libitum hingga berumur 2 minggu, dan selanjutnya diberi pakan remahan pelet sebanyak 3-10\% bobot tubuh per hari hingga akhir percobaan.

\section{Vaksinasi Maternal}

Pada percobaan ini digunakan dua kelompok induk yang dibedakan berdasarkan tingkat kematangan gonad (TKG), yaitu: (1) TKG I awal dan (2) TKG II awal. Penentuan kedua tingkat kematangan gonad tersebut dilakukan dengan cara sebagai berikut. Setelah menjalani proses adaptasi selama 2 minggu, induk betina diseragamkan perkembangan gonadnya dengan cara tidak diberi pakan selama tujuh hari; sehingga diharapkan telur-telur yang sedang berkembang dalam gonad diserap kembali sebagai sumber energi. Pada hari ke-7 dilakukan pemeriksaan terhadap tiga ekor sampel induk yang dibedah dan gonadnya diamati secara makroskopis. Hal ini dilakukan untuk meyakinkan asumsi perkembangan gonad yang hendak diterapkan dalam penelitian. Pada hari ke-8 hingga ke-11 induk betina mulai diberi pakan seperti biasa agar kondisi tubuh normal kembali, pada hari ke-12 diasumsikan sebagai permulaan perkembangan gonad atau TKG I awal dan dua minggu berikutnya diasumsikan sebagai TKG II awal.

Bakteri Aeromonas bydrophila isolat No.26 koleksi Balai Penelitian Perikanan Air Tawar yang disiapkan secara beat killed dengan kepadatan $1 \times 10^{11} \mathrm{cfu} / \mathrm{ml}$ digunakan sebagai vaksin. Pemberian vaksin kepada kedua kelompok induk yang berbeda tingkat kematangan gonadnya dilakukan melalui penyuntikan Intra Peritoneal (IP) dengan empat kelompok dosis, yaitu: (1) $0,2 \mathrm{ml} / \mathrm{kg}$; (2) $0,4 \mathrm{ml} / \mathrm{kg}$; (3) $0,8 \mathrm{ml} / \mathrm{kg}$ dan (4) kelompok ikan kontrol yang disuntik dengan Phosphate Buffer Saline (PBS).

\section{Pemijahan Ikan Uji}

Proses pemijahan serentak dari keseluruhan induk uji dilakukan setelah dua minggu dari saat pemberian vaksin kepada kelompok induk TKG II awal atau 
4 (empat) minggu dari saat pemberian vaksin kepada kelompok induk TKG I awal. Untuk menyeragamkan terjadinya ovulasi, semua induk dirangsang dengan ekstrak hipofisa dari ikan lele dumbo dengan dosis 1:1,5 bagi induk betina ( $1 \mathrm{~kg}$ resipien diberi ekstrak hipofisa yang berasal dari $1,5 \mathrm{~kg}$ donor) dan $1: 1$ bagi induk jantan.

Pada percobaan ini dilakukan dua tahap pemijahan. Pada tahap pertama, proses pemijahan induk uji dilakukan terhadap semua kelompok perlakuan; yaitu dua kelompok Tingkat Kematangan Gonad (TKG) atau Gonad Somatic Index (GSI) dan empat variasi dosis vaksin. Namun benih ikan dari hasil pemijahan tahap pertama ini hanya digunakan untuk keperluan pengamatan titer antibodi dan uji tantang I. Sedangkan pada tahap kedua, proses pemijahan hanya dilakukan terhadap kelompok perlakuan yang memberikan hasil relatif lebih baik berdasarkan hasil yang telah dicapai dari hasil pemijahan tahap pertama. Benih ikan dari hasil pemijahan tahap kedua digunakan untuk keperluan uji tantang II serta dipelihara dalam bak beton selama dua bulan sebagai aplikasi dari peran vaksinasi maternal.

\section{Titer Antibodi}

Pengamatan titer antibodi dilakukan terhadap serum darah induk sebelum diberi vaksin dan setelah proses pemijahan, ekstrak telur serta ikan uji pada saat berumur 7; 14; 21 dan 28 hari.

Serum darah induk diambil secara Dorsal Aorta Puncture (DAP), darah ditampung dalam eppendorf tube, kemudian diproses hingga didapat serum darah yang siap digunakan dalam pengamatan titer antibodi. Sedangkan ekstrak telur dan benih ikan diperoleh dengan cara mencuci telur maupun benih dengan akuades steril lalu dikeringkan di atas kertas saring Whatman. Telur dan benih berumur 7 hari digerus dengan penggerus ekstrak hipofisa, sedangkan untuk benih umur 14 hingga 28 hari ekstraksi dilakukan dengan menggunakan plastic stomacher.

Hasil ekstraksi berupa koloid dicampur dengan PBS Tween (v/v) yaitu larutan $0,13 \mathrm{ml}$ tween dalam $250 \mathrm{ml}$ PBS: $0,15 \mathrm{M}$; $\mathrm{pH} 7,2$ selanjutnya disaring dengan filter millipore 0,45 mikron meter kemudian hasil saringan dipusing pada $3500 \mathrm{x}$ g selama 20 menit. Setelah itu didiamkan selama 10-15 menit hingga terlihat tiga lapisan yang berbeda. Bagian atas merupakan lapisan lemak, kemudian cairan di atas endapan yang merupakan Soluble Extract (SE) diambil sebanyak 200-300 mikro liter. Cairan tersebut diduga merupakan campuran antara serum darah dengan cairan tubuh ikan dan diasumsikan sebagai serum darah yang nantinya digunakan dalam pengamatan titer antibodi. Sedangkan bagian paling bawah merupakan endapan jaringan tubuh ikan.

Pengukuran titer antibodi dilakukan dengan cara modifikasi menurut metode Anderson (1974). Pencampuran antara serum darah dengan antigen 
dilakukan dalam steril 96 well titertek plates, kemudian ditutup dengan aluminium foil dan disimpan dalam lemari pendingin selama 15-60 menit sebelum diperiksa. Sampel diperiksa dengan teknik tetes gantung dan diamati di bawah mikroskop compound pada pembesaran 400 kali.

\section{Pemeliharaan}

Ikan umur dua minggu dilakukan pemeliharaan dalam bak beton 1,5 x 2,25 $\mathrm{m}^{2}$ dengan kepadatan $150 \mathrm{ekor} / \mathrm{m}^{2}$ dan lama pemeliharaan selama 2 bulan. Pemeliharaan ini hanya dilakukan terhadap kelompok ikan uji yang memperlihatkan hasil baik, dan penentuan ini dilakukan berdasarkan hasil pengukuran titer antibodi dan uji tantang I. Pengamatan terhadap kondisi kesehatan ikan, gejala klinis pada ikan yang sakit serta tingkat kelangsungan hidup dilakukan setiap bulan dengan teknik pengambilan sampel total.

\section{Uji Tantang}

Untuk mengetahui peran kekebalan maternal pada masing-masing kelompok, dilakukan uji tantang terhadap patogen target sesuai dengan jenis yang diberikan pada induknya. Pengujian ini dilakukan dua kali, yaitu uji tantang I pada umur tiga minggu dan uji tantang II pada umur enam minggu. Pengujian I dilakukan terhadap semua kelompok ikan uji, sedangkan pengujian II hanya dilakukan terhadap kelompok ikan yang dipelihara dalam bak beton.

Uji tantang I dilakukan terhadap 100 ekor benih ikan dari masing-masing ulangan, dengan cara merendam ikan uji dalam media yang mengandung bakteri aktif dengan konsentrasi $1,0 \times 10^{7} \mathrm{cfu} / \mathrm{ml}$ selama 30 menit. Sebelum direndam dalam media tersebut, ikan uji terlebih dulu direndam dalam larutan bypersaline ( $5.000 \mathrm{ppm})$ selama 5 menit. Pemeliharaan selanjutnya dilakukan dalam akuarium dengan kepadatan 5 ekor/liter. Pengamatan terhadap gejala klinis secara makroskopis serta kematian dilakukan selama tujuh hari dari saat perendaman. Sedangkan uji tantang II dilakukan terhadap 25 ekor benih ikan dari masing-masing ulangan, dengan cara memasukkan bakteri aktif pada konsentrasi $1,0 \times 10^{3} \mathrm{cfu} / \mathrm{ml}$ sebanyak $0,05 \mathrm{ml} /$ ekor ke dalam tubuh ikan uji melalui penyuntikan intra muskular (IM). Pemeliharaan dan pengamatan selanjutnya dilakukan seperti pada uji tantang $I$.

\section{Analisis data}

Rancangan percobaan yang digunakan pada tahap pemijahan I adalah Rancangan Faktorial dengan faktor utama Tingkat Kematangan Gonad (2 perlakuan) dan dosis vaksin (5 perlakuan), namun karena terjadi kematian massal pada beberapa perlakuan maka data hasil tahap pemijahan tersebut digunakan sebagai percobaan pendahuluan. Sedangkan rancangan percobaan pada tahap pemijahan II adalah Rancangan Acak Lengkap (RAL) dengan 
variasi dosis sebagai perlakuan. Sedangkan untuk mengetahui perbedaan pengaruh dari masing-masing perlakuan digunakan uji jarak berganda Duncan.

\section{HASIL DAN PEMBAHASAN}

Hasil pengukuran titer antibodi yang dilakukan terhadap serum darah induk pra-pijah dan pasca-pijah memperlihatkan adanya proses induksi kekebalan spesifik pada kelompok induk yang divaksin. Meskipun tidak ditemukan perbedaan tingkat induksi yang berarti antara kelompok induk yang diberi vaksin pada tingkat kematangan gonad I dan II pasca-pijah, namun ada kecenderungan bahwa transfer kekebalan maternal pada benih yang dihasilkan kelompok induk yang disuntik pada TKG II lebih tinggi dibandingkan dengan benih yang dihasilkan oleh kelompok induk ber-TKG I. Hasil pengukuran titer antibodi yang dilakukan terhadap serum darah induk pra dan pasca-pijah, ekstrak telur, benih ikan umur 7; 14; 21 dan 28 hari terhadap bakteri target dapat dilihat pada Table 1 .

Table 1. Antibody titres of broodstock's blood serum before and after spawning, eggs extract and fries soluble extract 7, 14, 21 and 28 day old

\begin{tabular}{|c|c|c|c|c|c|}
\hline \multirow[t]{2}{*}{ Source } & \multirow[t]{2}{*}{ GSI } & \multicolumn{4}{|c|}{ Vaccine dosage $(\mathrm{ml} / \mathrm{kg})$} \\
\hline & & Cnt & 0.2 & 0.4 & 0.8 \\
\hline \multicolumn{2}{|l|}{$\begin{array}{l}\text { Broodstock before } \\
\text { spawning }\end{array}$} & 0.699 & 0.699 & 0.699 & 0.699 \\
\hline \multirow{2}{*}{$\begin{array}{l}\text { Broodstock after } \\
\text { spawning }\end{array}$} & $I$ & 0.477 & 1.230 & 1.519 & 1.519 \\
\hline & II & 0.477 & 1.519 & 1.519 & 2.111 \\
\hline \multirow[t]{2}{*}{ Egg } & $I$ & 0.301 & 0.699 & 0.954 & 1.230 \\
\hline & II & 0.301 & 0.954 & 1.230 & 1.519 \\
\hline \multirow[t]{8}{*}{ Fry } & $I$ & 0.301 & 0.477 & 0.699 & 0.699 \\
\hline & $I I$ & 0.301 & 0.699 & 0.954 & 0.954 \\
\hline & $I$ & 0.301 & 0.477 & 0.699 & 0.699 \\
\hline & $I I$ & 0.301 & 0.699 & 0.954 & 0.954 \\
\hline & $I$ & 0.301 & 0.477 & 0.477 & 0.477 \\
\hline & II & 0.301 & 0.477 & 0.699 & 0.699 \\
\hline & $I$ & 0.301 & 0.477 & 0.477 & 0.477 \\
\hline & $I I$ & 0.301 & 0.477 & 0.699 & 0.699 \\
\hline
\end{tabular}

Note: The number has been transformed from $\log ($ titer +1$) ; G S I=$ Gonad Somatic Index; Cnt = Control 
Pada Table 1 terlihat bahwa induksi antibodi pasca-pijah tertinggi diperoleh pada induk yang disuntik vaksin pada saat TKG II sebanyak $0,8 \mathrm{ml} / \mathrm{kg}$, sedangkan titernya masih terdeteksi hingga pengenceran ke-128. Namun untuk induk yang disuntik vaksin pada TKG II sebanyak 0,2 dan $0,4 \mathrm{ml} / \mathrm{kg}$ serta induk yang disuntik pada TKG I sebanyak 0,4 dan $0,8 \mathrm{ml} / \mathrm{kg}$ diperoleh kadar titer yang sama yaitu hingga pengenceran ke-32; kadar ini juga dicapai pada induk yang disuntik pada TKG I sebanyak 0,4 dan $0,8 \mathrm{ml} / \mathrm{kg}$.

Transfer antibodi dari induk yang divaksin kepada embrio (telur) pada mulanya memperlihatkan kecenderungan yang proporsional dengan tingkat induksi yang ada, namun setelah menetas menjadi larva (benih) laju peluruhannya bervariasi. Rukyani et al. (1995) menyatakan bahwa semakin tinggi kadar antibodi induk, cenderung menyebabkan bertambahnya kadar antibodi pada anaknya. Hal serupa juga telah dibuktikan pada ikan tilapia (Indrawarman, 1994) dan ikan lele (Pangaribuan, 1994).

Dari seluruh kelompok perlakuan, induk yang diberi vaksin pada TKG II awal memberikan tingkat induksi kekebalan yang lebih tinggi untuk semua dosis yang diperlakukan dibandingkan dengan yang diberikan pada saat TKG I awal; demikian pula dengan kadar yang ditransfer kepada keturunannya (Table 1). Takahashi dan Kawahara (1987) mengamati titer antibodi dari cairan tubuh ikan guppy hasil pemijahan vaksinasi maternal, kadar tertinggi didapat pada saat umur 0-1 hari yaitu hingga pengenceran ke-32. Taukhid dan Bastiawan (1993) mendeteksi adanya transfer antibodi induk pada kadar yang sama yaitu pada pengenceran ke-4 dari benih lele umur 28 hari hasil pemijahan induk yang disuntik vaksin sebanyak 1; 2; 3 dan 4 kali dengan dosis $0,2 \mathrm{ml} / \mathrm{kg}$ bobot badan. Sedangkan Pangaribuan (1994) yang menerapkan variasi konsentrasi vaksin, pada jenis dan umur benih ikan yang sama, tingkat pengenceran ke-4 hanya dicapai pada benih yang dihasilkan oleh kelompok induk yang dilakukan vaksinasi dengan konsentrasi $10^{10} \mathrm{cfu} / \mathrm{ml}$.

Dari beberapa hasil yang telah dicapai pada percobaan vaksinasi maternal, adanya transfer antibodi yang diukur dalam bentuk kadar titer antibodi merupakan informasi dasar yang menguatkan adanya proses transfer materi dari induk ikan kepada keturunannya. Transfer antibodi spesifik dari induk atau aktivitas aglutinasi telah diketahui pada telur ikan mas dan ikan plaice (Bly et al., 1986), pada anak ikan guppy (Takahashi dan Kawahara, 1987), pada telur tilapia (Mor dan Avtalion, 1988), pada embrio tilapia (Mor dan Avtalion, 1990), pada benih tilapia (Indrawarman, 1994 dan Sin et al., 1994), pada telur dan benih ikan lele dumbo (Taukhid dan Bastiawan, 1993 dan Pangaribuan, 1994). Relatif rendahnya transfer antibodi induk kepada keturunannya untuk tingkat proteksi yang aman secara teoritis antara lain disebabkan oleh teknik yang sangat sederhana dalam proses pengambilan dan pengamatan keberadaan antibodi dalam serum darah anak ikan.

Titer antibodi merupakan indikator adanya proses induksi kekebalan, sedangkan teknik untuk mengetahui efektivitas vaksin yang umum digunakan 
antara lain melalui uji tantang terhadap agen target (Ellis, 1988). Hasil uji tantang pada percobaan ini baik pada saat benih ikan berumur 21 hari maupun 35 hari disajikan pada Table 2.

Table 2. Mean of percentage mortalities of test fish on challenge I (21 old days) and challenge II (35 old days) to Aeromonas bydrophila

\begin{tabular}{cccccc}
\hline \hline Challenge test & GSI & \multicolumn{4}{c}{ Vaccination dosage $(\mathrm{ml} / \mathrm{kg})$} \\
\cline { 3 - 6 } & & Cnt & 0.2 & 0.4 & 0.8 \\
\hline I & I & 75.56 & 26.67 & 33.33 & nd \\
& II & 75.56 & 13.33 & 6.67 & 2.22 \\
& & $93.33^{a}$ & $68.33^{b}$ & $30.00^{c}$ & $58.33^{b}$ \\
\hline \hline
\end{tabular}

Note: $G S I=$ Gonad Somatic Index, Cnt $=$ control and $n d=$ no data. The average number followed by the same mark, not significant different on $5 \%$

Pada uji tantang I yang dilakukan terhadap seluruh kelompok perlakukan kecuali TKG I awal-dosis $0,8 \mathrm{ml} / \mathrm{kg}$, menunjukkan tingkat proteksi yang baik pada kelompok benih hasil vaksinasi maternal. Rataan mortalitas benih hasil vaksinasi maternal berkisar antara 2,22-33,33\%, sedangkan ikan kontrol sebesar $75,56 \%$. Pangaribuan (1994) melakukan hal serupa terhadap jenis dan umur ikan yang sama dari hasil vaksinasi maternal, rataan mortalitas berkisar antara 9-35\%; sedangkan ikan kontrol sebesar $68 \%$.

Hasil yang diperoleh pada uji tantang I memperlihatkan adanya korelasi positif antara kadar antibodi dengan tingkat proteksi terhadap agen target (Table 1 and 2). Namun pada uji tantang II (umur 35 hari) tidak memperlihatkan adanya korelasi tersebut. Pada uji tantang II tingkat proteksi paling tinggi dicapai oleh kelompok benih hasil induk yang divaksin dengan dosis $0,4 \mathrm{ml} / \mathrm{kg}$ dengan rataan mortalitas sebesar $30 \%$, kemudian diikuti oleh dosis $0,8 \mathrm{ml} / \mathrm{kg}$ sebesar 58,33\%, dosis $0,2 \mathrm{ml} / \mathrm{kg}$ sebesar $68,33 \%$ dan ikan kontrol sebesar $93,33 \%$ (Table 2). Analisis statistik terhadap persen mortalitas pada uji tantang II menunjukkan adanya perbedaan yang nyata pada taraf $95 \%(P<0,05)$.

Taukhid dan Bastiawan (1993) melakukan vaksinasi maternal dengan 1, 2, 3 dan 4 kali pemberian vaksin mendapatkan rataan mortalitas pada uji tantang terhadap benih umur 35 hari berkisar antara 0,33-1,67\% dan ikan kontrol sebesar 53\%. Sedangkan Pangaribuan (1994) terhadap jenis dan umur ikan yang sama berkisar antara $15-40 \%$ dan ikan kontrol sebesar $71 \%$. Tingginya rataan mortalitas yang didapat pada percobaan ini adalah karena perbedaan teknik infeksi, yaitu pada percobaan ini infeksi dilakukan melalui penyuntikan bakteri aktif sehingga proses infeksi langsung terjadi; sedangkan pada kedua percobaan lainnya teknik infeksi dilakukan melalui perendaman dalam larutan bakteri 
aktif sehingga proses infeksi sangat tergantung pada konsentrasi bakteri, jalan masuk (post of entry) dan lamanya waktu perendaman.

Pemeliharaan selama 2 (dua) bulan di lapang memperlihatkan adanya pengaruh vaksinasi maternal terhadap kelangsungan hidup ikan uji. Pada total sampling I, menunjukkan adanya perbedaan yang nyata antara kelompok ikan hasil vaksinasi maternal dengan ikan kontrol; demikian pula pada total sampling II. Meskipun secara analisis diantara kelompok ikan hasil vaksinasi maternal tidak menunjukkan adanya perbedaan yang nyata; namun secara visual kelompok ikan hasil vaksin dengan dosis $0,4 \mathrm{ml} / \mathrm{kg}$ lebih baik dibandingkan dengan dosis lain yang diterapkan. Hasil akhir pemeliharaan di lapang (Table 3) konsisten dengan hasil pada uji tantang II (Table 2).

Untuk mengetahui peran vaksinasi maternal di lapang, selama pemeliharaan diharapkan ikan uji menerima tekanan (stres) lingkungan yang besar melalui penebaran dengan kepadatan tinggi dan tidak dilakukan pergantian air; sehingga diharapkan hanya ikan-ikan yang memiliki stamina prima yang mampu bertahan hidup dan berkembang dengan baik.

Table 3. Mean of survival rate percentage of test fish on total sampling I and II

\begin{tabular}{ccc}
\hline $\begin{array}{c}\text { Vaccination } \\
\text { dosage } / \mathrm{kg}\end{array}$ & Total sampling I & Total sampling $\boldsymbol{I}$ \\
\hline Control & $53.07^{a}$ & $37.64^{a 1}$ \\
$0,2 \mathrm{ml}$ & $75.73^{b}$ & $71.67^{b 1}$ \\
$0,4 \mathrm{ml}$ & $80.40^{b}$ & $79.93^{b 1}$ \\
$0,8 \mathrm{ml}$ & $76.67^{b}$ & $69.01^{b 1}$ \\
\hline \hline
\end{tabular}

Note: The average number followed by the same mark, not significant different on 5\%

Konfirmasi secara integral melalui tiga pendekatan yaitu titer antibodi (Table 1), uji tantang (Table 2) dan aplikasi lapang (Table 3) untuk menilai hasil dari perlakuan yang diterapkan pada percobaan vaksinasi maternal ini, maka secara umum hasil yang lebih baik diperoleh pada kelompok ikan uji hasil pemijahan induk yang diberi vaksin 2 (dua) minggu sebelum pijah (diasumsikan sebagai TKG II awal) dengan dosis vaksin sebanyak $0,4 \mathrm{ml} / \mathrm{kg}$ berat badan.

\section{KESIMPULAN DAN SARAN}

Vaksinasi maternal merupakan salah satu alternatif dalam upaya pencegahan dini terhadap infeksi patogen potensial. Melalui vaksinasi ini, benih ikan yang 
dihasilkan telah dibekali antibodi spesifik yang ditransfer dari induknya sebelum larva/benih ikan mampu memproduksi antibodi sendiri.

Berdasarkan hasil-hasil percobaan dengan tiga aspek pendekatan yang berbeda yaitu titer antibodi, uji tantang dan aplikasi lapang yang diamati pada percobaan ini, hasil yang lebih baik diperoleh pada kelompok ikan uji hasil pemijahan induk yang diberi vaksin dua minggu sebelum pemijahan (diasumsikan sebagai TKG II awal) dengan dosis vaksin sebanyak $0,4 \mathrm{ml} / \mathrm{kg}$ berat badan.

Untuk pemanfaatan teknik vaksinasi maternal secara lebih luas dan mantap di lapangan, perlu dilakukan studi yang lebih intensif dan mendalam baik dari segi teknis maupun sosial ekonomi. Selain itu, perlu juga dilakukan studi transfer imunogenik dari patogen potensial lainnya melalui teknik vaksinasi maternal, terutama pada komoditas perikanan strategis lainnya.

\section{UCAPAN TERIMA KASIH}

Penulis mengucapkan terima kasih kepada Kepala Unit Pengembangan Budidaya Air Tawar (UPBAT) Cijengkol beserta staf yang telah banyak membantu selama berlangsungnya penelitian ini.

\section{DAFTAR PUSTAKA}

Anderson, D.P. 1974. Diseases of fishes. Book 4: Fish Immunology, Ed. by S. F. Snieszko and H.R. Axelrod, TFH Pub., Nepture City.

Bly, J.E.; A.S.Grimm and I.G.Morris. 1986. Transfer of passive immunity from mother to young in a teleost fish: haemaglutinating activity in the serum and eggs of plaice, Pleuronectes platessa L. Comp. Biochem. Physiol. Vol. 84A, No. 2, pp. 309-313.

Djajadiredja, R. dan F.Cholik. 1982. Penanggulangan Wabah Penyakit Ikan. Jurnal Litbang Pertanian. 1(1): 35-39.

Eidman, M., K. Sumawidjaja, S. Hardjosworo dan S. L. Angka. 1981. Wabah Penyakit Bercak Merah. Laporan Kelompok Kausal Team Crash Program Penanggulangan Epidemi Penyakit Ikan. IPB Bogor. 18 hal.

Ellis, A.E. 1988. Ontogeny of the Immune System in Teleost Fish. Fish Vaccination. Academic Press, London.

Indrawarman, I. 1994. Peran antibodi induk pada anak ikan tilapia terhadap Ichthyophthiriasis. Thesis, Program Pasca Sarjana, Institut Pertanian Bogor.

Johnson, K.A.; J.K. Flynn and D.F. Amend. 1982. Duration of immunity in salmonids vaccinated by direct immersion with Yersinia ruckeri and Vibrio anguillarum bacterins. J. Fish Dis., 5: 207-213. 
Kabata, Z. 1985. Parasites and diseases of fish cultured in the Tropics. Taylor and Francis, London Philadelphia. 317 p.

Kawahara, E.; T. Inarimori; K. Urano; S. Nomura and Y. Takahashi. 1993. Transfer of maternal immunity of white-spotted char, Salvelinus leucomaenis against furunculosis. Nippon Suisan Gakkaishi, 59(3): 567.

Mor, A. and R.R. Avtalion. 1988. Evidence of transfer of immunity from mother to eggs in tilapias. The Israeli Journal of Aquaculture (Bamidgeh), 40(1): 22-28.

Mor, A. and R.R. Avtalion. 1990. Transfer of antibody activity from immunized mother to embryo in tilapias. Journal of Fish Biology, 37: 249 . 255.

Pangaribuan, T.N. 1994. Pengaruh vaksinasi Aeromonas bydropbila Stainer pada induk lele dumbo (Clarias gariepinus Burchell) terhadap kelangsungan hidup benihnya. Thesis, Jurusan Perikanan, Fakultas Peternakan, Universitas Padjadjaran, Bandung.

Rukyani, A.; Taukhid dan Kamiso H. N. 1995. Immunisasi Maternal: Suatu teknik baru dalam penanggulangan penyakit ikan. Jurnal Penelitian \& Pengembangan Pertanian Vol XIV, Nomor 1. Badan Penelitian dan Pengembangan Pertanian. Hal. 1-5.

Sin, Y.M.; K.H. Ling and T.J. Lam. 1994. Passive transfer of protective immunity against ichthyophthiriasis from vaccinated mother to fry in tilapias, Oreocbromis aureus. Aquaculture, 120: 229-237.

Takahashi, Y. and E. Kawahara. 1987. Maternal immunity in newborn fry of the ovoviparous guppy. Nippon Suisan Gakkaishi, 53(5): 721.725 (In Japanes).

Taukhid dan D. Bastiawan. 1993. Kekebalan bawaan (maternal immunity) pada benih ikan lele (Clarias sp.) hasil pemijahan induk yang divaksin antiAeromonas bydrophila. Prosiding Seminar Hasil Penelitian Perikanan Air Tawar 1992/1993 (In Press). 
Appendix 1. Specific antibody titres on Aeromonas bydropbila from broodstock before and after vaccination, eggs, larva of $7 ; 14 ; 21$ and 28 days old

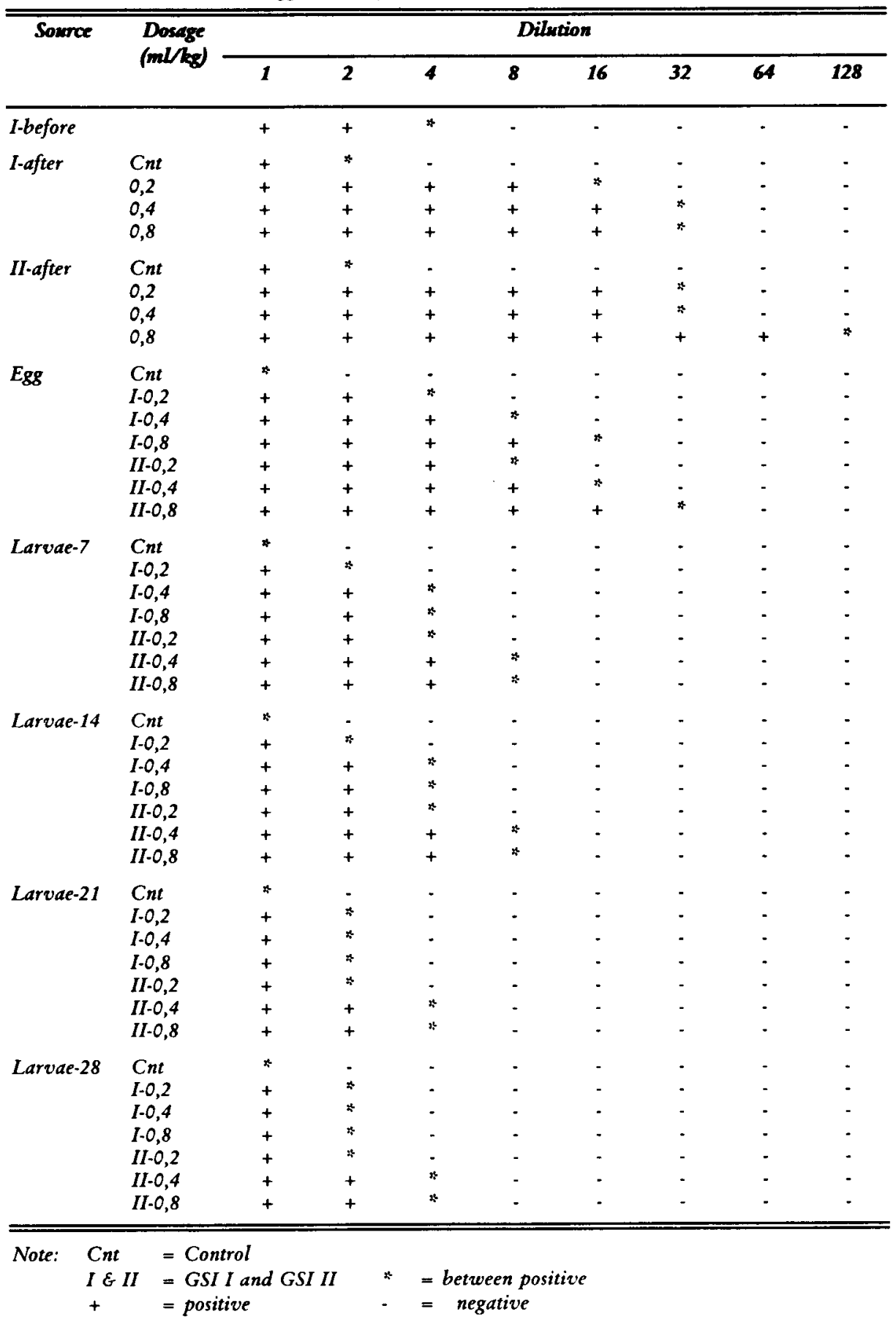

